\title{
Gender asymmetries in Portuguese trade unions: The case of the CGTP-IN
}

European Journal of Women's Studies 2022, Vol. 29(I) 54-7I

(C) The Author(s) 2020 Article reuse guidelines: sagepub.com/journals-permissions DOI: 10.1 I 177/I3505068209790I0 journals.sagepub.com/home/ejw

๑SAGE

\section{Maria Helena Santos $(D)$}

Instituto Universitário de Lisboa (ISCTE-IUL), CIS-IUL, Lisboa, Portugal

\section{Carla Cerqueira}

Lusófona University - CICANT, Porto, Portugal

\section{Rui Vieira Cruz}

Centro Interdisciplinar de Ciências Sociais. NOVA - Universidade do Minho (CICS.NOVA-UMinho), Braga

Centro de Estudos em Comunicação e Sociedade (CECS), Braga, Portugal

\begin{abstract}
Gender imbalances persist throughout the world, particularly at leadership level, and equally also visible in the case of trade unions. This article focuses on CGTP-IN, the largest Portuguese trade union confederation, and sets out analysis incorporating both figures from this organisation and accounts by female members of CGTP-IN unions. Results confirm the existence of gender asymmetries, especially at the highest leadership levels. Analysis of the discourses of these women leaders reveals some awareness of the influence of gender on professional relations, placing women at a disadvantage, especially where leadership is concerned. Furthermore, four reasons driving the persistence of these gender asymmetries in trade union leadership/decisionmaking roles were identified: family responsibilities, gendered professional segregation, masculine trade union cultures and traditional gender stereotypes. Nevertheless, the interviewees resist to means of affirmative action such as gender quotas, and instead prefer to prioritise education and raising awareness around gender equality.
\end{abstract}

\section{Keywords}

Affirmative action, asymmetric leadership, CGTP-IN, gender inequalities, trade unions

\section{Corresponding author:}

Maria Helena Santos, ISCTE - Instituto Universitário de Lisboa, CIS-IUL, Av. das Forças Armadas, I649-026 Lisboa, Portugal.

Email: helena.santos@iscte-iul.pt 


\section{Introduction}

Over recent decades, gender equality became an objective for Western societies (EIGE, 2018) with a correspondingly significant presence on the governance agendas of various civil society organisations, including trade unions. This has led to major transformations in diverse professional contexts, pursuant to the rising numbers of women in varied different traditionally male professions and occupations. In Portugal, the prolonged dictatorial regime and ensuing emigration, military mobilisation and colonial war led to the early (1960s) entry of women into the labour market (Lopes and Perista, 2010). The country is marked by extensive, full-time labour market participation of women, high levels of female qualification and progressive gender equality legislation (Amâncio and Correia, 2019). However, gender inequalities persist across assorted spheres (CIG, 2017) and, somewhat paradoxically, trade unions represent no exception (Alves, 2017).

There is a vast body of international research on trade unions. ${ }^{1}$ This research reveals considerable changes in the working world, industrial relations and models of political economy, as well as in the trade union movement itself, despite the specific characteristics inherent to each country. Over the last half century, and greatly boosted by the second wave feminism, trade union organisations have displayed clear progress where inclusion of women is concerned, in terms of both members and collective representation mandates, noticeably deriving from structural reforms and affirmative action policies (see Kirton, 2018).

However, moments of clear resistance to change, particularly visible in the leadership positions, have also endured and, at present, a 'hostile socio-economic/political context threatens to hinder further progress' (Kirton, 2018: 344). Indeed, even when some leadership positions are held by women, they are not yet 'critical mass' (Cockburn, 1996: 11) and encounter difficulties in making their voices heard (Bertolin and Kamada, 2012). According to cited authors, women experience a process of 'excluded inclusion' which is prevalent in their integration into trade unions, as well as the employment market (Bertolin and Kamada, 2012: 47). Kirton (2018) notes that this process also befalls Black, Asian and Minority Ethnic (BAME) groups, with BAME women thus subject to double exclusion (Cockburn, 1996: 1). These phenomena may stem from inclusion of women having been, to a certain extent, imposed on trade unions, coupled with failure of unions and wider societies to accompany this inclusion with questioning of the prevailing androcentric organisational culture. Organisations remain profoundly sexist and thereby still generate certain perverse effects, such as allocating women to specific sectors of activity deemed 'feminine' (subordinate and less valued positions) and the continued existence of the 'glass ceiling' (Guillaume, 2007; Monney et al., 2013).

Until the end of the 20th century, the large majority of research in this field unfolded with an ethnic and gender-neutral perspective (Healy and Kirton, 2000; Kirton, 2018), a trend which has been offset in recent decades (particularly in the aforementioned studies). Within this framework, we would state that trade unions, like other organisations, are both gendered (Acker, 1990) and racialised (Acker, 2006), with all of the negative consequences this entails for women - especially minorities women - and the disadvantages they experience in comparison with their middle-class, White, male peers. 
The present article uses this gender lens (Cooper, 2012), interlinking it with categories such as ethnicity, class and age (Acker, 2006; Briskin, 2006; Kirton, 2018), to look at Portugal where, to our knowledge, intersectional perspective (Crenshaw, 1991) is nonexistent and research on gender and trade unions remains scarce. Among studies we identified, we highlight Ferreira (2002), Santana (2009) and Alves (2017), who report on a gender setback in terms of trade union leadership over the preceding decade.

After outlining the theoretical framework underpinning this study, we present our analysis, focused on the General Confederation of Portuguese Workers - National InterUnion (CGTP-IN), ${ }^{2}$ the largest active confederation of Portuguese trade unions. First, we examine the number of men and women within the diverse organisations and the positions they hold, focusing on the senior leadership and decision-making positions. Subsequently, we provide accounts from 10 White female union leaders, gathered via semi-structured interviews, with the purpose of clarifying the existence (or otherwise) of gender awareness in professional relations and practices, as well as identifying the reasons behind the persistence of gender or other asymmetries in trade union leadership/ decision-making bodies, along with perceptions on the ways and means to resolve such imbalances.

\section{Gender inequalities in trade unions}

The trade union world is masculine (Cockburn, 1996). A review of the Portuguese trade union movement's history (Alves, 2017) confirms that the relationship between women and unions has been difficult from the earliest days of industrialisation and the organisation of workers at international level. From the outset, there was a type of generalised sexist strategy that sought first to exclude or segregate women in the labour market, leading to women founding their own trade unions in various countries, including Portugal. Second, after having been, to a certain extent, forced to include women (due to women's mass entrance into the labour market, especially from the 1960s onwards, and the acquisition of more civil and political rights), unions fought to maintain their under-representation in the organisation, particularly at leadership levels (Alves, 2017; Ferreira, 2002; Santana, 2009).

While registering progress, European Trade Union Confederation (ETUC) confirmed a persistence of under-representation of women and highlighted that 'the confederations from the countries of southern Europe [including Portugal; comment by author] and the Mediterranean basin and eastern Europe being strongly dominated by men' (Alves, 2017: 162-163).

Male domination seems so deeply rooted that even where there is overwhelming female trade union membership, there is no guarantee of similar levels of representation in decision-making positions (Healy and Kirton, 2000). This occurs notwithstanding some progress since the end of the 20th century, largely due to women's trade union struggles (Kirton, 2018) and to structural reforms and affirmative action policies, implemented to foster greater equity between women and men (e.g. see Alves, 2017; Bertolin and Kamada, 2012; Ledwith, 2012; Ledwith and Munakamwe, 2015; Marsh et al., 2014). The practice of inclusion certainly does not correspond to the rhetoric (Ledwith and Munakamwe, 2015), with clear and strong resistance registered towards efforts designed 
to foster greater gender and 'race'/ethnic equality in androcentric trade unions (Monney et al., 2013), and sexist and masculinist (Cooper, 2012) or racist (Kirton, 2018) organisational cultures. As Ledwith (2012: 198) summarises, 'study after study, especially those articulating women's own experiences, identifies the enduring power of the culture of hegemonic masculinity'. Correspondingly, trade unions may be perceived as 'co-actors of progress in equality, due to the practices, strategies and policies developed, but also providing resistance to their implementation' (Monney et al., 2013: 35, our translation into English). The resistance becomes stronger whenever approaching the most senior leadership positions where the gender imbalance still remains far greater, 'occurring even in countries where the political participation of women stretches back further and more intensely and/or where their proportion in the group of full-time staff is higher than that of men' (Alves, 2017: 164, our translation). However, 'the representation of women and their concern in trade union structures (. . .) is an issue (. . .) of gender democracy' (Cockburn, 1996: 25).

Various reasons have been identified in explanation of these gender disparities that exist particularly at leadership level. ${ }^{3}$ Le Quentrec et al. (2002) proposed this is socially constructed, stemming from a general attribution of women to the private sphere and men to the public. Furthermore, as trade unions are an integral part of labour markets, the prevailing occupational and industrial gender patterns become reproduced in the trade unions (Ledwith, 2012). Castro (1998: 90) also details how women in leading trade union positions in Brazil emphasise that 'the public and private are intertwined, and that women's roles in the domestic sphere indeed limit women's participation in the public sphere both materially and symbolically'. According to Briskin (2006), in 1995, the 'Women and Decision Making in Trade Unions' report on the national trade union confederations of 31 countries identified four major barriers to women as a generic group: (1) family responsibilities, (2) professional segregation, (3) masculine trade union cultures and (4) traditional stereotypes (Briskin, 2006: 4). An ETUC study on the Caribbean concluded the under-representation of women in trade union decision-making positions partly derives from (1) the existence of prejudice towards women conveyed through hostile reactions and attempts to dissuade them from taking on trade union responsibilities, (2) the rigidity of certain procedural rules, (3) the lack of confidence among women in their own abilities and (4) the male-dominated nature of trade union culture (Marsh et al., 2014). In fact, Marsh et al. confirm that women are marginalised from command positions due to the prevailing cultural norms and established masculine hegemony, a situation that has been perpetuated by men, but also by women attributing leadership to men. The belief persists that 'women are unequal to men and that men have a 'right' to exercise power and privilege over women in the home as in the society' (Vassell, 2006, cited by Marsh et al., 2014: 42-43). Leadership continues to be culturally perceived as a process requiring attributes particularly associated with masculinity (e.g. such as rationality, objectivity and authority). Women are ranked as inadequate for leadership due to the supposed combination of various biological and socially stereotyped factors (e.g. considered naturally fragile, passive, submissive, indecisive and emotional).

Healy and Kirton (2000) note that, once elected, trade union leaders tend to remain in office and deploy all their resources to annul attempts challenging their leadership. As such, "challenges to the existing order by "outsiders," including women, are likely 
to prove unsuccessful. The democratically elected leadership becomes oligarchic and reproduces male domination, such that unions may be described as gendered oligarchies' (Healy and Kirton, 2000: 344). Thus, trade unions cannot be perceived as 'race' or gender-neutral (Acker, 1990, 2006) and application of these arguments to trade unions demonstrates how gender and other intersections mark and shape these organisations. Trade unions are 'fundamentally constituted by culture and the informal norms and every day cultural practices are rarely gender neutral' (Wajcman, 2000: 196, cited by Ledwith, 2012: 195) or race and class-neutral (Acker, 2006). Connell (2002) argues that the 'gender order', predominant in any specific society, also influences the organisational dynamics and is capable of strengthening gender asymmetries or 'gender regimes' in organisations.

Thus, considering gender and the other intersections under analysis is paramount, as these are inherently part of a process that may not be appropriately understood through recourse to neutral analysis that otherwise ignores all the underlying power dynamics (e.g. Connell, 2002). According to Acker (2006: 443), all organisations have 'inequality regimes' that she defines as 'loosely interrelated practices, processes, actions, and meanings that result in and maintain class, gender, and racial inequalities within particular organizations'. As for trade unions, the time has arrived for greater inclusiveness and changing the "union script from the old slogan "in unity is strength" to "in diversity is strength"” (Kirton, 2018: 354).

\section{The trade union world of Portugal - The CGTP-IN case}

Trade union membership in Portugal is strictly voluntary across both the public and the private sectors, and the country is not signatory of the Ghent model ${ }^{4}$; thus, the trade unions do not receive any state financing. Membership fees are paid by unionised workers with a percentage of their wages. This specificity of the Portuguese case contributes to the low union density (16\%) compared to $72 \%$ of employees covered by collective bargaining (Organisation for Economic Co-operation and Development (OECD), 2017).

Founded in 1970, the CGTP-IN is one of the oldest still active trade union confederations in the country. It played a key role in labour disputes throughout history, ranging from the reduction of the working hours to the abolition of child labour.

There are institutional concerns around inclusion and diversity-related issues within the CGTP-IN, addressed by the creation of three specific organisations: Inter-Youth, Inter-Retirees, and the Department of Equality Commission for Women and Men, established in 2004 to address the gender inequality and its scope of influence (CIMH, 2008). However, the CGTP-IN has not implemented any type of affirmative action to foster greater gender equality in its trade unions, such as quotas or a parity policy. Nevertheless, CGTP-IN union did implement an Action Plan to reduce unequal pay and gender gaps (Pillinger, 2014). In addition, it has developed campaigns and information material focusing on equality between women and men at work (CIMH, 2019).

It is important to stress that, given the persistence of gender inequalities in Portuguese society, there has been a rather proactive attitude on behalf of the government in recent decades within the framework of bringing about greater equality. Two types of affirmative action were adopted - one in the political context (the so-called Parity Law: Organic 


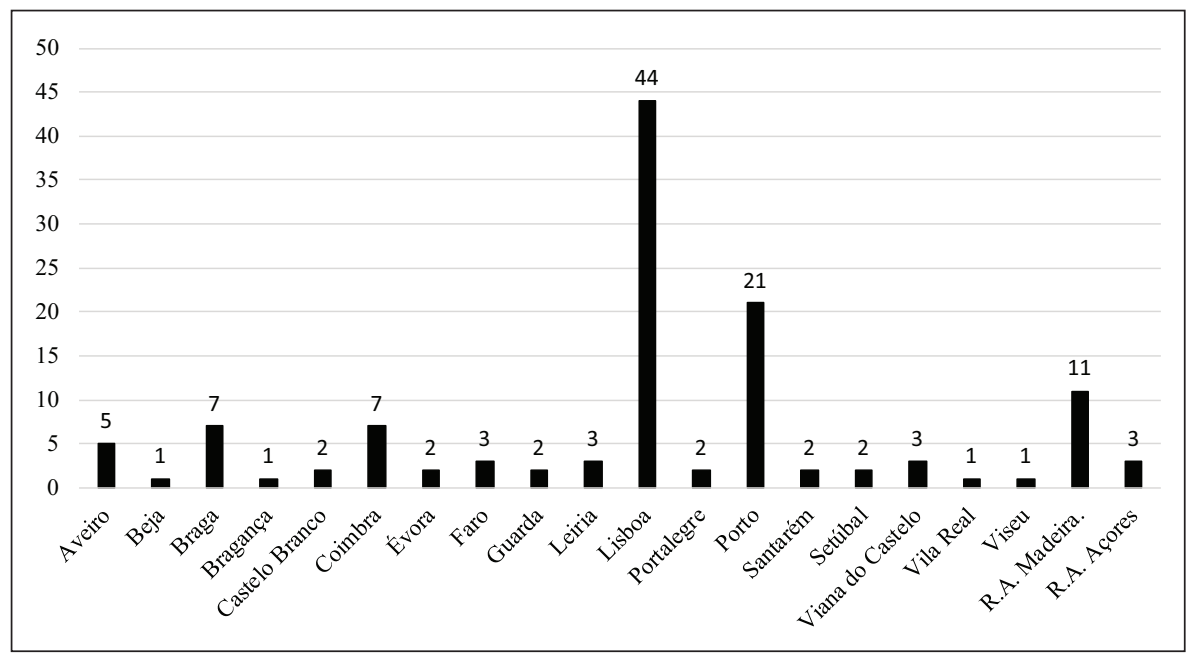

Figure I. Distribution of the CGTP-IN trade union universe by district.

Law no. 3/2006, 21 August, revised in 2019) and the other in the business sector (Law no. $62 / 2017,1$ August, applies to both state-owned and listed companies) - potentially able to influence other sectors, such as trade unions.

The CGTP-IN internal organisation spans five bodies: the Congress; the National Plenary ${ }^{5}$; and the National Council - with its 147 members: 96 men (65.3\%) and 51 women (34.7\%). It has the Executive Commission - with a maximum of 30 members and currently containing 20 men (66.7\%) and 10 women (33.3\%); the Secretariat, which needs a maximum of seven persons (presently having 6, 4 men $(66.7 \%)$ and 2 women $(33.3 \%)$ ); and, finally, the Supervisory Council comprised of unions rather than individuals.

The trade union membership of CGTP-IN contains a total of 151 organisations that break down into 2 confederations, 10 federations, 22 district unions, 4 local unions, 2 regional coordinators and 111 trade unions spatially covering all of the Nomenclature of Territorial Units for Statistics (NUTS) regions of Portugal. While the confederations and federations are national in scope, the district unions, the local unions, the regional coordinators and the trade unions deploy a sphere of participation that more closely focuses on the local/regional levels.

\section{Sample}

We sought to obtain the maximum amplitude and coverage of the 123 organisations in total ( 2 confederations, 10 federations and 111 trade unions) that make up the universe under study (distributed by district as detailed in Figure 1). We gathered information about the composition of their power structures and social bodies (especially for Boards, General Assemblies and Audit/Supervisory Boards/Councils), categorising the members by sex (male, female). The data were obtained from the CGTP-IN website and covers filiate and partner unions. District and local unions and regional coordinators were not 
Table I. Sample distribution by sector of activity.

\begin{tabular}{lcc}
\hline Sector of activity & $\begin{array}{l}\text { Number of } \\
\text { trade unions }\end{array}$ & Percentage \\
\hline Healthcare & 8 & 17.39 \\
Teachers & 7 & 15.22 \\
Energy & 6 & 13.04 \\
Banking/Insurance/Services & 6 & 13.04 \\
Civil/Municipal Government & 5 & 10.87 \\
Industrial (food, cork, etc.) & 3 & 6.52 \\
Telecommunications & 3 & 6.52 \\
Navy/Army & 2 & 4.35 \\
Architecture/Engineering/History & 2 & 4.35 \\
Sport & 1 & 2.17 \\
Judicial & 1 & 2.17 \\
Industrial (textile, footwear) & 1 & 2.17 \\
Transport & 1 & 2.17 \\
Total & 46 & 100 \\
\hline
\end{tabular}

part of this study, as they are composed of trade unions and not individuals, preventing identification of their make-up by gender.

Trade unions from the fields of healthcare, education (teachers), energy and banking/ insurance/services account for $67.57 \%$ of the sample (see Table 1 ).

As set out in Figure 2, the two main trade union CGTP-IN confederations register a third of women in their leadership but only the CPQTC - the Portuguese Confederation of Technical and Scientific Staff - attains a value above $40 \%$.

The six CGTP-IN federations we analyse are majority male, with the exception of the teachers trade union (Teachers National Federation - FENPROF). Furthermore, only two federations achieve a one-third female level of representation - FENPROF and FESETE (Federation of Trade Unions of Textile, Wool, Clothing, Footwear and Leather Workers of Portugal), with only the latter achieving a $40 \%$ level of representation. These also represent some of the fields of work women are commonly associated with. Among the diverse forms of trade union organisation, the federations are the only structures that do not register even one-third of women within board membership (toping at 29\%; see Figure 3).

Of the 46 trade unions we analysed, only 8 (17.4\%) report a greater number of women than men in their leadership. These span sectors of activity connected with education $(62.5 \%)$, the textile industry $(12.5 \%)$, healthcare $(12.5 \%)$, and retail and services $(12.5 \%)$ thus interlinked with markedly feminised professional sectors (see Figure 4).

Of these eight trade unions, five $(62.5 \%)$ have less than one-third male representation in their leadership structures, with the SINPICVAT (textile) and SPE (teachers) having over $90 \%$ female leadership and CESP (retail and service) reporting $66.96 \%$ female leadership. We would stress that the organisation websites only provided sex disaggregated data, so we have not been able to access information on race, ethnicity or age of the leadership members. These would be important to deepen the discussion on the inequality 


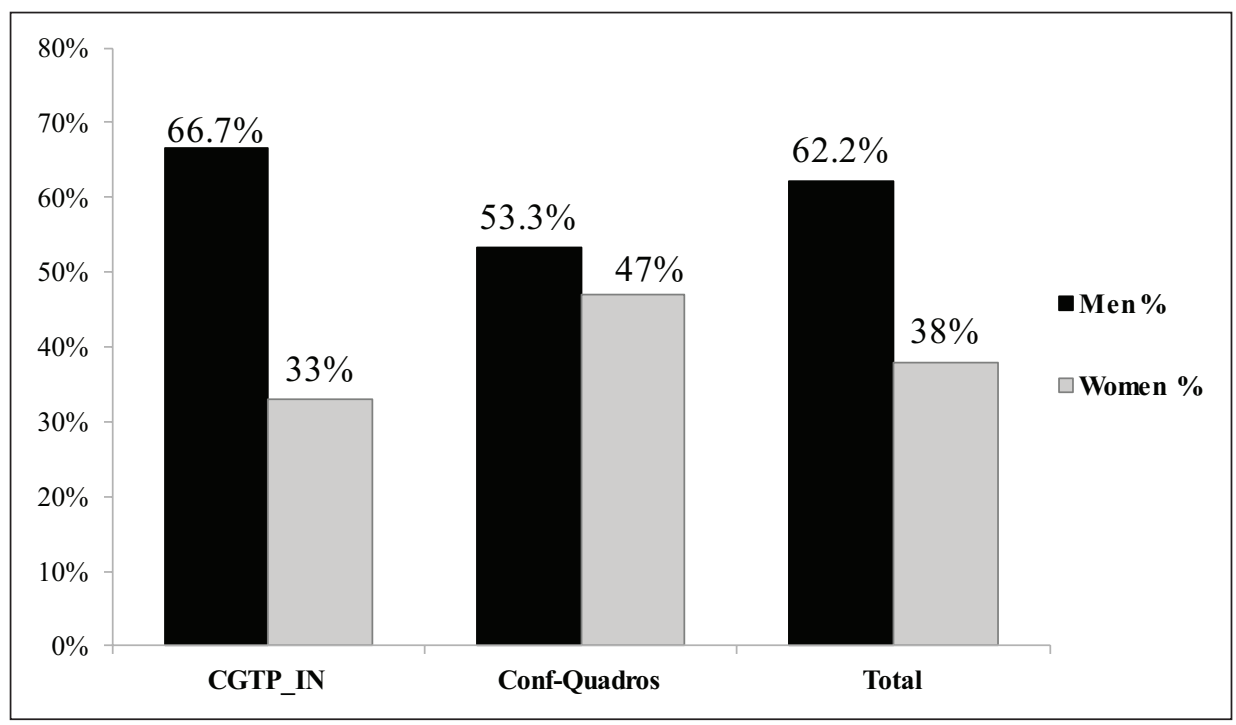

Figure 2. Distribution of CGTP-IN trade union confederations by sex.

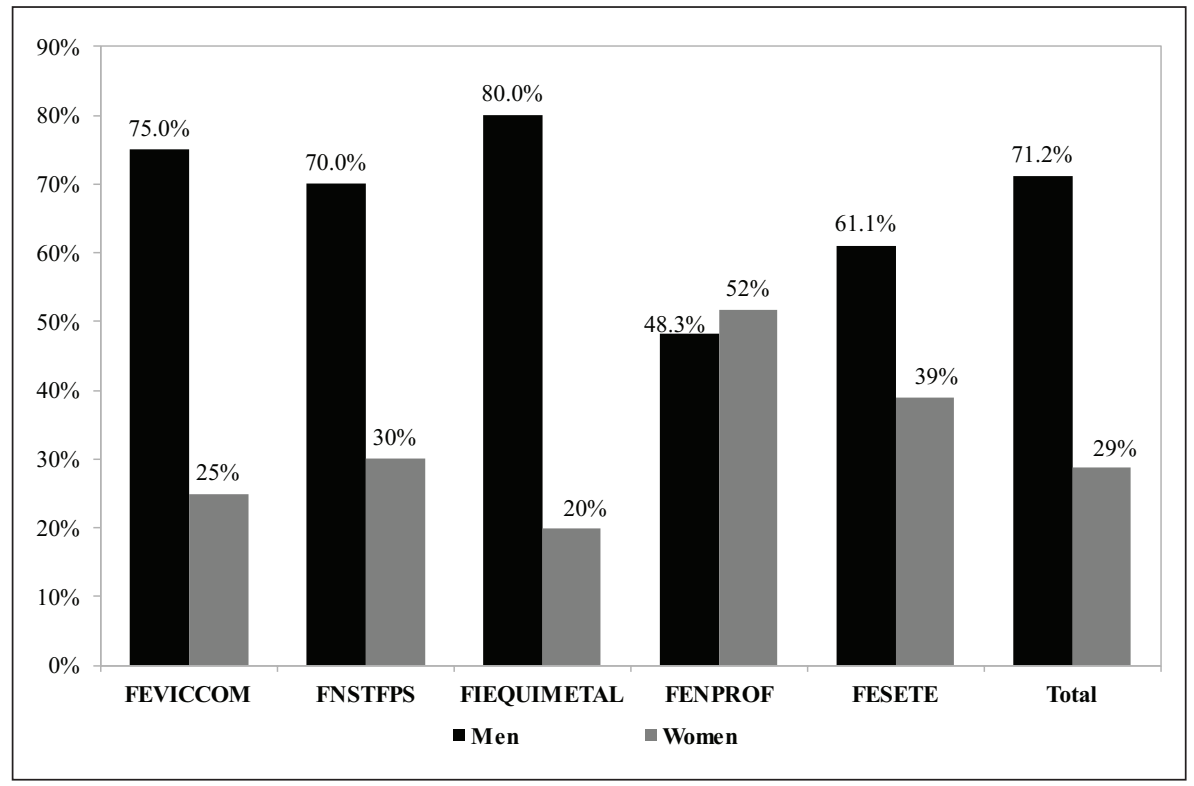

Figure 3. Distribution of CGTP-IN federation by sex.

regimes' (Acker, 2006) prevailing within trade unions. Nevertheless, it is important to hear the voices of women who hold leadership positions and hence the relevance of the second part of this study. 


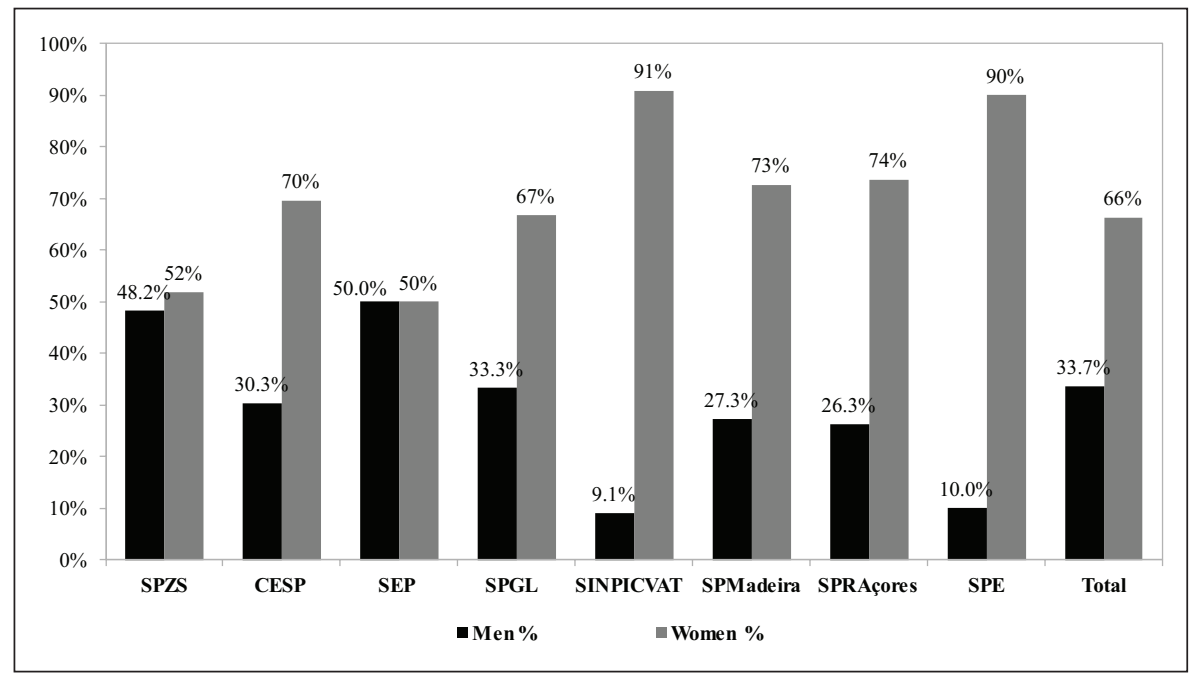

Figure 4. Eight trade unions with the highest representation of women.

\section{Gender inequalities in trade union organisations - Some discourses}

Participants and procedures. Ten semi-structured interviews took place with 10 women in CGTP-IN trade unions' leadership positions, age between 39 and 70 years ( $M=50.7$ years; $S D=10.3$ years), a majority of whom are from healthcare and public service sector. Save for one, they all have tertiary education (two of them master's degree). One woman is widowed, one divorced, all other married.

We adopted a convenience sample chosen according to the 'snowball' techniques that started out with personally contacting a CGTP-IN member and concluded at information saturation. The subsequent contacts were then undertaken via e-mail and complemented by phone calls presenting the general objectives of the study and guaranteeing confidentiality and anonymity. To that end, we do not reference participants' respective trade unions. The interviews took place between June 2018 and February 2019 with the locations varying between public spaces (e.g. coffee shops) and trade union headquarters, with one interview made through Skype. Average interview length stands at around 40 minutes. We recorded the interviews with the prior consent of interviewees, and then completed full transcriptions and analytical procedures.

The interview script broached the issues discussed within the theoretical framework, spanning personal career paths in the trade union, the situation of gender inequality in the trade union leadership and the means of overcoming such inequalities, including affirmative action measures.

Following exploratory data analysis through application of NVivo 12 software, thematic analysis (Braun and Clarke, 2006) emerged as the most appropriate approach, enabling 'identifying, analyzing and reporting patterns (themes) within data' (Braun and Clarke, 2006: 79) through bringing about an understanding of the explicit and implicit meanings associated with the textual data (Guest et al., 2012). 


\section{Results}

We identified two major themes: one closely focused on the barriers/obstacles to gender equality and the other dealing with the means of resolving gender inequality in trade unions.

\section{Barriers to gender equality}

The first main theme, around barriers to gender equality, identifies four subthemes closely related to the barriers identified by Braithwaite and Byrne (1995, cited by Briskin, 2006): family responsibilities, gendered professional segregation, masculine trade union cultures and traditional gender stereotypes.

Family responsibilities. All interviewees, except one, contributed to the first subtheme. In the discourses on the barriers and difficulties hindering access to senior trade union positions, the issue of family responsibilities was highlighted, conveying how these still fall more heavily on women and become an added difficulty, especially when lacking either family or third-party support (e.g. a household cleaner or maid). This correlates with time management and the issue of family/work 'balance', especially as regards domestic duties and caring for children which, while there is evidence of greater gender equality, continue to remain more a female responsibility and for which trade unions have not yet produced any formal measures in response (e.g. nurseries):

It depends on each case, each sector. There are problems of a family nature that may, at that time, hinder . . . even when identifying that this is a member of staff with great potential, able to make a most wonderful contribution but that person has other responsibilities, young children or sick parents that require attention . . . (I1, CGTP, age 62)

As Castro (1998) detailed in his study of women in leadership positions in a Brazilian trade union, our interviewees also make it clear how the public and private are intertwined, and that women's roles in the domestic sphere do indeed limit their participation in the public sphere both materially and symbolically.

Gendered professional segregation. Most participants (8 out of 10) demonstrated recognition of the gender inequalities in the working world, highlighting discourses around gendered professional segregation, such as 'glass ceiling', gender wage gap and moral harassment. According to No 1, Art. 29 of the Labour Code, 'moral harassment' is

an unwanted behaviour (gesture, word, attitude . . . ) based on a discriminatory factor, practised when accessing employment or in one's own job, work or professional training with the aim or effect of upsetting or embarrassing the person, affecting their dignity, or creating an intimidating, hostile, degrading, humiliating or destabilising environment.

What is in Portugal called 'moral harassment' includes things elsewhere called 'sexual harassment' and women clearly point that they are its biggest victims. In fact, in the Portuguese context, according to the study 'Sexual and Moral Harassment in the Workplace' 
(Torres et al., 2016), 16.7\% of women have experienced moral harassment compared to $15.9 \%$ of men. It should be noted, however, that sexual harassment is reported by $12.6 \%$ of respondents, with $14.4 \%$ of women and $8.6 \%$ of the men surveyed. As stated in the study's summary, harassment, both moral and sexual, is most often perpetrated by men, on women, and on other men, and most often affects women - a manifestation of male dominance and making the workplace a place of reproduction of the beliefs and practices of gender discrimination prevalent in Portuguese society.

In fact, the interviewees made references to areas external to unions, specifically companies and organisations, and attributed greater recognition of gender discrimination outside than within the trade unions. These results do not necessarily mean that there are effective improvements within trade unions with respect to rooted male cultures, but that the interviews were focused on the trade unions' strategy to combat gender inequalities and that it was outward looking, for companies. Interviewees refer to various examples of gendered professional segregation in the labour market and the 'glass ceiling' as illustrated by the following extract:

As a norm, men assume the senior positions and women get the intermediate positions and that is what we currently see (. . .). In the intermediate positions, there are more women, in the middle management. I cannot recall any hospital that has had a woman as the president of its board. Are there many women clinical directors, or women vowel members', for example, on the board of directors? How many public hospitals are there in Portugal? I don't recall even one woman. That's a very small minority. (I3, Healthcare, age 39)

Interviewees also note that, in general, company leaders do not appreciate having trade union activists in the professional context (they are perceived as 'agitators') and this reflects in intimidatory pressures and constant moral harassment that personally and professionally impact union members. To avoid 'reprisals' or 'penalties', they often opt to keep their union membership secret:

There are colleagues who don't want it to be known that they're unionised; not because of their colleagues or even the doctors but rather because of the leadership. They think they may suffer some repercussions. (I5, Healthcare, age 52)

However, there is also perception that this moral harassment is gendered, with references highlighting that women are more harassed and encounter more difficulties in affirming themselves in a world in which the most senior leaders are older men:

Women face more difficulty in self-affirmation and I think they are subject to more moral harassment. In the field of surgery it's more complicated. In general surgery, there are now more women but there used to be more men. It's easier to bully a woman than a man (. . .). The male leaders don't have as much respect for women. It's easier for an older man who has the profile of 'I want, I can and I order' to abuse a woman than to abuse a man. (I3, Healthcare, age 39)

Trade union masculine culture. All the interviewed women gave examples of masculine trade union culture, even when they personally did not display any gender awareness or 
named those examples gender discrimination. Pointing to how unions serve as counterbalance to companies and organisations, they approach the question of leadership with an oscillation between the recognition of a masculine culture and the denial of any ongoing discrimination.

Gender aware respondents accept that there is still a long path ahead before achieving gender equality in this sector. However, they see this as understandable, as a cultural problem and a mere reflection of the gender asymmetries prevailing in other contexts, such as family and professional domains. Nevertheless, they remain convinced that this reality is changing:

In a classical family, for example, with a man and woman, the distribution of people is also $50 / 50$ but that does not mean the domestic duties are divided equitably. If there is here a cultural problem in family management, well then, we may expect that some of these differences will appear in professional and trade union lives. (I7, Civil Service, age 51)

Another discursive facet conveys how this matter of gender in/equality in trade unions very much depends on the professional field: finding more men in leadership in professions deemed masculine, and more women in the healthcare field, nursing or in other more 'female' fields of medicine:

Participation in leadership is commonly seen among those who have the availability and who want to do so. I, when I prepare the lists of potential leaders, have two concerns: ensuring the representation of all levels and all areas of the career structures. This is the first concern that we have and I hold responsibility for preparing and then communicating and requesting everybody's collaboration. And there are also areas in which it is easier to find women and those where men are easier. It's not so much . . . not so much about the actual representation by specialist field. (I2, Healthcare, age 70)

Furthermore, some of those interviewed believe that there is no longer any gender inequality or discrimination in trade unions, while also believing this depends on organisational structure:

We are a small structure. Our transversal contacts are simpler than the vertical. We play things down with each other. In the discussions among ourselves, you do not notice any male discourse or female discourse, you just don't see that. (I2, Healthcare, age 70)

Analysing the various discourses, we find that women internalise masculine trade union culture, which interweaves with the 'gender order' (Connell, 2002) that remains in the macro culture. Thus, some of them - even when talking about examples of discriminatory practices - did not actually recognise them as gender discrimination.

Traditional gender stereotypes. Half of those interviewed gave examples of being directly addressed through traditional gendered stereotypes even though some of them did not always show any awareness that what they talked about are the stereotypes. They oscillated in their discourses between talking about stereotypes without questioning them, and explicitly expressing the need for their deconstruction through education and collective civic training in order to advance in the direction of more equal societies: 
I recognise, when looking around, that there is a problem with the representation of women in top positions, also at the level of trade unions. And this is something that is in our hands to counter and reverse. Otherwise, we may continue defending equality from the point of view of principles, but they will not end up getting implemented (. . .). There is a need to at least partially counter the status quo in which it is natural that the men have greater availability [to leadership positions]. This is not at all natural and is a sign that women face far more obstacles to reaching this type of positions. (I10, Education, age 59)

\section{Means of resolving gender inequalities in trade unions}

The second major theme drew contributions from all interviewees, albeit in a fairly heterogeneous manner, especially on issues around affirmative actions (such as gender quotas as institutional policies). On occasion, trade unions do seem to show concerns over complying with the percentages established by such measures. However, the majority of interviewees expressed extreme positions either in favour of or against gender quotas, and clearly link these with the gender dynamics that constitute obstacles to offsetting gender inequalities. In fact, we identify here two subthemes: (1) support for affirmative actions as institutional measures and (2) resistance to such actions on the grounds that such measures are no longer necessary for attaining gender equality and perceiving them as a type of 'necessary evil' for achieving more rapid progress in this field (especially because only a few trade unions foster any type of alternative measure), but which are not deemed priorities, especially because of a belief that the investments need to target the areas of education and awareness.

Favourable positions on affirmative action. In Portugal, affirmative actions and quotas have had positive effects in both the political context and the business world. While some describe other steps towards gender equality that might be more 'naturally' taken, the prevailing feeling among interviewees is that quotas represent the 'lesser evil', helping 'to strengthen alterations rooted in mental attitudes coming about more swiftly' (E7). Interviewees feel that it is better not to pursue a single universal and inflexible logic but rather be malleable and strive to gradually overcome the reality of organisations. They suggest that, instead of demanding 50/50 parity, it might be better to retain the one-third proportion that seems to be adequately flexible and will, in time, progressively head in the direction of equality and underpin this idea:

I think we would be a lot better if we began by imposing quotas. We cannot be inflexible (. . .). And this is not just about men and women but also between newer members and those who are longstanding. Otherwise, we run the risk of always getting the same people. (I9, Retail, Banking and Services, age 44)

Positions against affirmative action. Some of the interviewees were against the 'imposition' of affirmative action measures, such as gender quotas, on the grounds of preferring instead to invest in education and awareness raising in the workplace so that women wish to join and participate in trade unions. They place greater emphasis on representation, not only of women but also of inclusion of young persons in trade unions, but without the need for any institutional norms. Almost all of the women interviewed raised the issue of 
age as a priority for trade unions even within an intergenerational logic. One interviewee also focuses on the importance of striving for the diversity of membership, warning of the need to recruit migrants. This conveys how inequality regimes (Acker, 2006) remain very much present in trade unions, with intersectional view (Crenshaw, 1991) lacking. They note that some social groups - such as migrants - are underrepresented in trade unions.

Finally, there is a certain resistance to affirmative action measures such as gender quotas as institutionalised measures but there also seems to be an informal concern in most trade unions about including the percentage established in the existing law:

I think we should work every day with this [i.e. equal representation] in mind but I'm not a big defender of implementing the Quotas Law in every case. (I4, Healthcare, age 43)

In general, there seems to be few trade unions engaging in any type of alternative to gender quotas in order to advance gender equality:

We don't have [any trade union strategy]. It would be important; yes indeed, it would be positive if we were able to implement some strategies to facilitate the participation of women. But we don't have any. We have never taken any measures in this field. Not now and not in the past. (I10, Education, age 59)

\section{Conclusion}

Despite the undeniable progress towards gender equality made generally in Portuguese society, the trade union world seems to have remained masculine. In fact, data analysis on the largest Portuguese trade union confederation - the CGTP-IN - confirms the existence of gender imbalances and gendered logics, particularly in what concerns the highest leadership decision-making positions, which continue to be male dominated. This is in keeping with the findings of other international (e.g. Bertolin and Kamada, 2012; Cooper, 2012) and national (e.g. Alves, 2017; Santana, 2009) studies. As no structural reforms and affirmative action policies have been adopted to promote greater equality, trade unions and federations tend to replicate the existing labour market gender differences. Therefore, only professions with heavy female presences in their workforces (e.g. textile, nursing, teaching) also display more women in leadership roles at local levels.

Analysis of the interviewee discourses show that many, but not all the trade union women leaders display some gender awareness as regards professional relations and practices. Recognising the current situation as far from ideal, they perceive the existence of gender inequalities not only in the working world but also in the trade union contexts that place women at a disadvantage, especially as regards attaining leadership positions.

In fact, in line with Braithwaite and Byrne (1995, cited by Briskin, 2006), these trade unionists put forward four main reasons for the persistence of gender asymmetries within this latter scope: (1) family responsibilities that continue to demand more of women, thus leaving them less available to dedicate to the engagement in the union; (2) the persistence of gendered professional segregation that continues to place women at a disadvantage in comparison with men, especially at vertical level (with phenomena such as the 
'glass ceiling' clearly visible) but also in terms of salaries and forms of treatment with perceptions of moral harassment prevailing, which proves a greater problem for women; (3) trade union cultures that, generally speaking, remain markedly masculine, particularly those connected to the more masculine professional contexts with all of the resulting negative implications for women; and (4) the traditional gender stereotypes that, while not always subject to questioning by the interviewees, are identified as penalising women to a greater extent and certainly constitute yet another obstacle to their career progression. These testimonies from interviewees confirm that these 'gender regimes' (Connell, 2002) in trade unions reflect the 'gender order' prevailing in society, reproducing their systems and values (Acker, 1990). Some of the interviewed women sometimes speak of the leadership in a way that does not show awareness of gender discrimination and inequality even when they themselves have experienced them. But some of them also do not fail to point out the existence of gender inequalities and sometimes express very precisely an 'excluded inclusion' (Bertolin and Kamada, 2012).

We would emphasise, however, that the interviewed women clearly show that organisations have 'inequality regimes' (Acker, 2006) that operate at the level of standards, organisational practices and daily interactions. These organisational cultures end up reproducing the situations of inequality that happen in the surrounding host society. They are expressed, for example, when addressing difficulties in reconciling schedules or when respondents state that younger women and those with dependents experience more difficulties. Interviewees also mention that younger and older people and migrants, among others, are often absent from trade unions. It should thus be stressed that the interviewee discourses point to several groups that still remain absent or poorly represented while raising the need to consider inclusion from a more intersectional perspective.

Simultaneously, it is important to note that research needs to target intersections between vectors of multiple discrimination, which were stressed in the interviews, specifically gender, age and migratory status that produce inequality regimes (Acker, 2006). There is also the issue of race that seems absent from trade union organisational concerns (which do not collect information on this issue). Race has also been noticeably absent from the scientific and social debate, but recently re-emerged with great emphasis in the Portuguese context. This watchful gaze over greater identity complexity in organisations is central to deconstructing the obstacles that seem to persist in these environments and that block the inclusion and visibility of certain women in leadership positions.

In summary, in keeping with other international research results (e.g. Briskin, 2006; Le Quentrec et al., 2002; Marsh et al., 2014), the persistence of gender asymmetries would seem to derive above all from the gendering of professions, of trade unions and of the private sphere that all continue to contain barriers to the career progression of women, consequently restricting their achieving leadership and decision-making roles in those trade unions.

Despite this, and the scarcity of measures enacted by the trade unions themselves, the interviewees display positive attitudes towards the future, understanding that, 'over time', there has been evolution in the direction of gender equality, and include the trade unions within this scope. They also reveal some resistance to affirmative action measures, such as gender quotas, as imposed institutional measures on the grounds that more education and greater awareness around the problems of gender inequalities is a higher 
priority. In effect, the discourses in favour and against this type of measures are fairly diverse, seen as a type of 'necessary evil' and/or a complement to other strategies for achieving more rapid changes in mentalities and attaining gender equality. This aspect has already been reported in other studies of women in leadership positions, for example, in politics (Santos and Amâncio, 2016).

Hence, in addition to recognising inequalities and the existence of gender asymmetries in trade unions, especially as regards their leaderships, this research concludes that there is still a long path ahead in Portugal. To this end, there is at least the need to design and implement equality measures and monitor plans for addressing, and redressing organisational practices and cultures in which gender asymmetries remain very visible and that enable internal resistance as well as repercussions against union members throughout the spheres of labour and employment.

\section{Acknowledgements}

We would here thank the female trade unionists who kindly agreed to be interviewed.

\section{Declaration of Conflicting Interests}

The author(s) declared no potential conflicts of interest with respect to the research, authorship, and/or publication of this article.

\section{Funding}

The author(s) disclosed receipt of the following financial support for the research, authorship, and/ or publication of this article: This work was supported by the National Foundation for Science and Technology (FCT) in Portugal (under the PEST Grant number UID/PSI/03125/2013).

\section{ORCID iD}

Maria Helena Santos (iD https://orcid.org/0000-0001-7708-4634

\section{Notes}

1. Some studies focus on various single countries, including Australia (e.g. Cooper, 2012), Brazil (e.g. Bertolin and Kamada, 2012), the Caribbean (Marsh et al., 2014), France (e.g. Guillaume, 2007) Switzerland (Monney et al., 2013) and the United Kingdom (e.g. Healy and Kirton, 2000; Ledwith, 2012) Other studies take comparative perspective, for example, Brazil and South Africa (Ledwith and Munakamwe, 2015), the United States and Canada (Kaminski and Jailza, n.d.), and the United Kingdom and the United States (Kirton et al., 2010).

2. Confederação Geral dos Trabalhadores Portugueses-Intersindical Nacional (CGTP-IN).

3. See Bertolin and Kamada (2012), Briskin (2006), Castro (1998), Healy and Kirton (2000), Kaminski and Jailza (n.d.), Kirton et al. (2010), Le Quentrec et al. (2002), Ledwith and Munakamwe (2015), and Marsh et al. (2014).

4. The Ghent system is an international agreement stipulating that welfare payments are made by trade unions rather than by government agencies. As workers need to be unionised in order to receive economic and social benefits, the countries that signed the agreement tend to have higher union memberships.

5. No sex disaggregated data on Congress, but every unionised person can enter. The National Plenary is comprised of the unions and not individuals. 


\section{References}

Acker J (1990) Hierarchies, jobs, bodies: A theory of gendered organizations. Gender \& Society 4(2): 139-158.

Acker J (2006) Inequality regimes: Gender, class, and race in organizations. Gender \& Society 20(4): 441-464.

Alves PM (2017) Da exclusão à sub-representação - dois séculos de relações problemáticas entre sindicatos e mulheres. Journal of Studies on Citizenship and Sustainability 3: 158-177. Available at: http://civemorum.com.pt/artigos/1/JSCS.3_PAlves_p158.177.pdf

Amâncio L and Correia RB (2019) Em busca da igualdade. Percepção de justiça e divisão do trabalho doméstico - mudanças e continuidades. Sociologia, Problemas e Práticas 90: 77-94.

Bertolin PTM and Kamada FL (2012) Ausentes ou invisíveis? A participação das mulheres nos sindicatos. Caderno Espaço Feminino 25(1): 28-52. Available at: http://www.seer.ufu.br/ index.php/neguem/article/view/13656 (accessed 10 April 2019).

Braun V and Clarke V (2006) Using thematic analysis in psychology. Qualitative Research in Psychology 3(2): 77-101.

Briskin L (2006) Union leadership and equity representation. Paper for the union module of the gender and work database. Available at: http://www.genderwork.ca/gwd/wp-content/ uploads/Briskin_Union-Leadership_Paper_April_2006.pdf

Castro MG (1998) The gendered (Di)-vision of the rebellion: The public and the private in life histories of female and male union leaders, Salvador-Bahia-Brazil. Identities: Global Studies in Culture and Power 5(1): 65-96.

CIG (2017) Igualdade de género em Portugal: Boletim estatístico 2017. Available at: https:// view.publitas.com/cig-comissao-para-a-cidadania-e-igualdade-de-genero/boletim-estatistico-2017/page/1 (accessed 11 April 2019).

CIMH (2008) História da CIMH. Available at: www.cgtp.pt/cgtp-in/organizacoes-especificas/ comissao-de-igualdade-mulheres-homens/1180-historia-da-cimh (accessed 14 April 2019).

CIMH (2019) Guia prático. Igualdade entre mulheres e homens no trabalho. Available at: http:// www.cgtp.pt/images/images/2019/07/CGTP_Guia_Pratico.pdf (accessed 15 July 2020).

Cockburn C (1996) Strategies for gender democracy: Strengthening the representation of trade union women in the European social dialogue. European Journal of Women's Studies 3(1): $7-26$.

Connell RW (2002) Gender. Cambridge: Polity Press.

Cooper R (2012) The gender gap in union leadership in Australia: A qualitative study. Journal of Industrial Relations 54: 131-146.

Crenshaw K (1991) Mapping the margins: Intersectionality, identity, politics and violence against women of color. Stanford Law Review 43: 1241-1299.

EIGE (2018) Study and work in the EU: Set apart by gender. Review of the implementation of the Beijing Platform for Action in the EU Member States. Report. Available at: http://cite.gov.pt/ pt/destaques/complementosDestqs2/Studyandwork.pdf (accessed 20 July 2019).

Ferreira V (2002) O efeito Salieri: o sindicalismo perante as desigualdades entre mulheres e homens no emprego. Revista Critica de Ciências Sociais 62: 121-148.

Guest G, MacQueen KM and Namey EE (2012) Applied Thematic Analysis. Thousand Oaks, CA: SAGE.

Guillaume C (2007) Le syndicalisme à l'épreuve de la féminisation. La permanence 'paradoxale' du plafond de verre à la CFDT. Politix 78(2): 39-63.

Healy G and Kirton G (2000) Women, power and trade union government in the UK. British Journal of Industrial Relations 38(3): 343-360. 
Kaminski M and Jailza P (n.d.) Union leadership and gender: Obstacles for women. Labor and worklife program, Harvard University. Available at: https://silo.tips/download/union-leadership-and-gender-obstacles-for-women (accessed 2 December 2020).

Kirton G (2018) Unions and equality: 50 years on from the fight for fair pay at Dagenham. Employee Relations 41(2): 344-356.

Kirton G, Healy G, Alvarez S, et al. (2010) Women and Union Leadership in the UK and USA: First Findings from a Cross-National Research Project. London: Queen Mary University of London. Available at: http://digitalcommons.ilr.cornell.edu/reports/28/ (accessed 20 April 2019).

Le Quentrec Y, Rieu A and Lapeyre N (2002) Femmes dans la prise de décision politique et syndicale: pour quels changements? UTINAM, Revue de Sociologie et d'Anthropologie 5: 59-85.

Ledwith S (2012) Gender politics in trade unions. The representation of women between exclusion and inclusion. Transfer: European Review of Labour and Research 18(2): 185-199.

Ledwith S and Munakamwe J (2015) Gender, union leadership and collective bargaining: Brazil and South Africa. The Economic and Labour Relations Review 26: 1-19.

Lopes MC and Perista H (2010) Trinta anos de educação, formação e trabalho: convergências e divergências nas trajectórias de mulheres e de homens. In: Ferreira V (ed.) A Igualdade de Mulheres e Homens no Trabalho e no Emprego em Portugal. Politicas e Circunstâncias. Lisbon: CITE. Available at: http://cite.gov.pt/asstscite/downloads/publics/Igualdade_CITE_ NET.pdf (accessed 20 July 2020), pp. 191-216.

Marsh L, Phillips MA and Wedderburn J (2014) Gender and trade union development in the anglophone Caribbean. Caribbean Quarterly 60(3): 39-57.

Monney V, Fillieule O and Avanza M (2013) Les Souffrances de la femme-quota. Le cas du syndicat suisse Unia. Travail, Genre et Sociétés 2(30): 33-51.

Organisation for Economic Co-operation and Development (OECD) (2017) Employment database - Labour market policies and institutions. Available at: http://www.oecd.org/employment/ emp/employmentdatabase-labourmarketpoliciesandinstitutions.htm (accessed 16 July 2020).

Pillinger J (2014) Bargaining for equality. European Trade Union Confederation, 1-86. Available at: https://www.etuc.org/en/publication/bargaining-equality (accessed 14 July 2020).

Santana V (2009) Géneros nos sindicatos: Igualdades, desigualdades e diferenças. Lisboa: Ministério do Trabalho e da Solidariedade Social, Direcção-Geral do Emprego e das Relações de Trabalho.

Santos MH and Amâncio L (2016) Gender inequalities in highly qualified professions: A social psychological analysis. Journal of Social and Political Psychology 4(1): 427-443.

Torres A, Costa D, Sant'Ana H, et al. (2016) Assédio sexual e moral no local de trabalho em Portugal. Lisboa: Centro Interdisciplinar de Estudos de Género, Comissão para a Igualdade no Trabalho e no Emprego. Available at: http://cite.gov.pt/pt/destaques/complementosDestqs/ Assedio_Sexual_Moral.pdf(accessed 8 September 2020).

Wajcman J (2000) Feminism facing industrial relations in Britain. Britain Journal of Industrial Relations 38(2): 183-201. 